\title{
New perspectives to Nigeria's foreign policy towards China
}

\author{
Oluwole Gabriel Adekola* \\ Department of International Relations Faculty of Administration Obafemi Awolowo University Ile-Ife, 22005, \\ Osun State, Nigeria, West Africa.
}

\begin{abstract}
This study focused on the new perspectives to Nigeria's foreign policy towards China. It assessed the opportunities presented by the rise of China for Nigeria's foreign and domestic policies. This was with a view to identify strategies that can accommodate the growing power of China while consolidating the gains of Nigeria's interactions with the Western powers. The central argument is that Nigeria need to restructure its foreign policy to accommodate the new realities of China's emergence as a global economic power. Explicating this new frontier in foreign policy administration in the context in which Nigeria has traditionally focused on Western Europe and North America in her foreign policy outlook constitutes the main problematic of this study. This study relied on primary and secondary sources. The sample size used for the interview was 25 respondents. Since the study is a qualitative research, the descriptive method of data analysis was employed. The study among other things reveals that: the constraints imposed by Nigeria's near-total reliance on the policy directives of the leading Western economies since the beginning of the 21st century adversely affected its pace of development; and that the nature of Nigeria's economy is partly a function of some of its unsuccessful domestic and foreign policies. It concludes that there is a dire need to restructure Nigeria's foreign policy.

Keywords: Nigeria-China interaction, foreign policy, development, oil for infrastructure/cash.
\end{abstract}

\section{Introduction}

This study brings to fore some of the status quo that must give way to a new paradigm. It considers the implication of continual interaction of Nigeria with the West in a rapidly changing World Order. Nigeria's economy is perceived here as having been structured by the capitalist West to ensure that existing international division of labour allocated to it remains - the role of supplying raw materials and importing finished goods from the industrialized West. Other perspective is that foreign owned extractive industries and agriculture formed monopoly enclaves which serve as a conduit pipe for resources overflow from Nigeria (Nigeria Business Times, 2007: 42). The economic welfare of Nigeria must no longer be dependent on foreign capital. Nigeria must be able to fulfill the role of raising national productive power for development so as to avoid being submerged in a vicious unsustainable debt and a circle of underdevelopment. Both Washington and Brussel in the mind of many Nigerians seems to have done everything virtually possible to subjugate the political and economic interest of the country which includes domestic capital flight and installing puppet regimes or pseudo democracies in the past.

The underpinning of bilateral or multilateral economic relations between Nigeria and its traditional allies is that trade between the industrialized nations of the West and Nigeria is screened in terms of unequal domestic power relationships, institutional and economic rigidities and a dual economy. This has enlarged the transfer of wealth and resources to the industrialized countries and promoted the overflow of profits and dividends to multinational business that are headquartered in Europe, North America and Japan from subsidiaries in Nigeria. Given this backdrop, it is of utmost necessity that the nation's policy makers should guide against pitfalls in its new relationship with China. Amadu Sesay (2008), a professor of International Relations, warned that Nigeria should not make the same mistake it has made with the West, as China is neither to be seen as a Third World nation nor a wonderful bride to behold as far as Africa is concerned.

Alaba Ogunsanwo (2008: 16-17) seems to corroborate Sesay's fears about the sincerity in China's developmental intentions in Nigeria by saying that China "cannot honestly be extremely enthusiastic in encouraging the conversion or transformation of crude oil exporting countries such as Nigeria, to petroleum products exporting countries"(Ogunsanwo, 2008:17). This is because "China needs for her industry enormous amounts of imported crude oil and is looking for this everywhere including Angola, Sudan, Nigeria, and Gabon and wherever else in Africa such oil is accessible". ${ }^{8}$ While Amadu Sesay would have us be bothered to ask where China veers from and not just embrace her, Fawole $(2008)^{1}$, a renowned expert in Nigerian Foreign Policy obliged scholars and policy makers to be mindful of possible hypocritical gang up against China, as relatedly, most of the heinous atrocities perpetrated in Africa from ages has been greatly supported by the West. Depending on the angle from which any of the scholars sees the Chinese's involvement in a Third World country like Nigeria, one thing is certain, and that is summarily settled in a foremost diplomatic saying that there is no free lunch in the international system. 


\section{The Nigerian Dimension in China's Foreign Policy}

The foreign policy objectives conception of China for Nigeria is derivable from the African take of its global cardinal objectives. These could be abridged as follows:

i). creating a well secured environment for economic development

ii). seeking outlets for more trade and investment with China

iii). getting regional states reassured that they ought not to feel threatened by the rise of China.

iv). weakening the capacity and willingness of the regional nations to truncate the rise of China; ensuring that international support for "containment" is reduced.

v). securing and diversifying access to natural resources, energy supplies

vi). ensuring that Taiwan's "international space" and the ability of others to ascribe status and legitimacy to it (Taiwan) is reduced.

It is pertinent to note that over time, these strategies are not equally emphasized by China among different nations and regions. China perceives of its external environment as one devoid of any major power conflict in the future but believes growing tensions and contradictions among major powers are in place due to the policies of the US; that globalization is both pervasive and enduring: soft power, less zero-sum-ness, economic power important, high degree; in China's conception, the hegemonic unipolar dominance of the US is likely to be sustained in the next twenty years and the pace at which multi-polarity is developing presently is too slow; emergence of non-traditional security challenges; increasing desire for resources and energy security; and the rising China's involvement in global affairs as a new force for shaping rules, norms and global institutions (Medeiros, 2006).

Articulated in Medeiros' memoirs on its foreign policy approach to the world, China is believed to perceive the global arena from three points of view. Firstly, is how it may reclaim its lost status as an internationally respected great power, hence it focuses on rejuvenation and revitalization while having strong and pervasive mentality. Secondly, is victimization at the hands of the Western powers that violated China's sovereignty and territorial integrity thereby remembering the century of shame and humiliation that ended only in 1949. Thirdly, is the security outlook with which China seek to maximize its security and its independence or autonomy. This insight makes China to seek freedom from external threats and curtailment on its actions.

\section{Nigeria's Foreign Policy Objectives}

The fundamental objectives and directive principles of state policy in Nigeria's Constitution itemized the country's foreign policy thus:

i). promotion and protection of the national interest;

ii). promotion of African integration and support for African unity;

iii). promotion of international cooperation for the consolidation of universal peace and mutual respect among all nations and elimination of discrimination in all its manifestations;

iv). respect for international law and treaty obligations as well as seeking of settlement of international disputes by negotiation, mediation, conciliation, arbitration and adjudication; and

v). promotion of a just world economic order. ${ }^{1}$

It is necessary to note here that analysts have pointed out significant loop holes inherent in the constitution by not being specific about "the actual content and direction of the country's foreign policy" (Fawole, 2004: 9). Similarly, it has been observed that these flaws in the constitutional provision bestowed upon the shoulder of the president the responsibility to determine the specific contents and direction of the nation's foreign policy (Fawole, 2000: 218-231). This is not too good for a country like Nigeria even in the twenty-first century when nations of the world with which it relates have well articulated domestic and foreign policy with direction. Indeed, such provisions, when in place, would definitely assist the nation not to be off the track from state specific interests as it plays along in the international arena.

\section{IV. "Oil for Infrastructure" or "Oil for Cash" approach?}

If Nigeria were just any old developing world 'ant', the Chinese government could, conceivably, have just turned its back on it and concentrated on its relations with others. But the country has 'superpower' features that make it impossible to ignore: its enormous oil reserves, to which China still wants access; a substantial appetite for new infrastructure; and a large population with growing consumer demands. So the Chinese government has changed tack, agreeing to go along with the new Nigerian government's preferred 'oil for cash' approach. \{Gregory Mthembu-Salter in South African Institute of International Affairs Occasional Paper No 42 (China in Africa Project), Sept., 2009: 24-25\}.

Quotation from Gregory Mthembu-Salter (above) aligns with the position taken by Wong and Utomi, the latter who doubled as co-presidential candidate of another party with Obasanjo and as a scholar of no small measure. To them, the key element of Obasanjo's policy towards China may best be summarized as 'oil for infrastructure'. In a clearer term, Obasanjo required that Chinese and other Asian bidders that preferred oil blocs 
to include in their bids a commitment to provide Nigeria with major infrastructural projects (Wong, 2009; Utomi P, 2008: 40). The motivational factor for this policy seems to be the growing frustration and disillusionment of the Nigerian government with what looks like paltry dividends accruing from the West since its near fifty years of post-independence interaction with the latter, together with its irritation with the cumbersome conditionalities of Western aid, ${ }^{2}$ and partly due to the fact that Obasanjo was personally highly impressed with the infrastructure he saw during his visit to China (Synge R, 2008: 886).

The 'oil for infrastructure' policy was essentially Obasanjo's regime's. This policy seems to have died a natural death at the close of his tenure when Umaru Musa Yar'Adua (deceased) took over as president of Nigeria after the 2007 highly controversial general election. ${ }^{3}$ Some steps taken by the Late Yar'Adua's administration to review the 'oil for infrastructure' policy agreements signed between the Nigerian government and Asian oil companies, which have almost resulted in the suspension or cancellation of these contracts according to a very senior civil service official's participant observation, the process depicts as if it was the opposition, rather than same and the ruling party the former and incumbent presidents both belong. There are ethno-political colorations to the doing of things, and in this connection, to policy decision making in the country that players must realize. Restructuring of some of these contracts, take it or leave it, must take account of the changed ethno-political realities of a new political leadership. It must be noted that both the former president Obasanjo and Late president Yar,Adua hailed from different geo-political zones of the country, coupled with differing religious tenets. While Obasanjo is a Yoruba man from the country's Christian south, Late Yar,Adua was of Hausa Fulani extraction and a Muslim from the north. Save the Yar'Adua's northern supporters' interest was taken care of in the prior deals by Obasanjo, there was the likelihood that agreements in place would be truncated. ${ }^{4}$ The 'oil for infrastructure' policy was transmuted to 'oil for cash' policy which rendered the Chinese government's bid during Obasanjo's second tenure in office to secure Nigerian oil assets a failure as Chinese companies only able to retain blocs for which they have fully paid.

If not that Nigeria is well endowed, according to Mthembu-Salter (quoted in full above), "the Chinese government could, conceivably, have just turned its back on it (Nigeria) and concentrated on its relations with others". He perceives Nigeria as an enigma - a state that appears to wield the superpower posture in Africa, and especially its West African sub-region. Pat Utomi had asked, "what is the government's China policy?" This question presupposes that the Nigeria government has a China policy. It is debatable. From all indications, it appears the Nigerian government is unsure of what it wants to do about same. ${ }^{5}$ A view of a senior opposition member of the foreign affairs committee of Nigeria's House of Representatives which echoed that of Utomi states thus:

I don't think (that) there is a China policy. The government is very inward looking and there is a serious foreign policy vacuum. The foreign minister lacks the skills for the job. We lack a functioning foreign policy think-tank, and the foreign ministry is a kind of joke. It is like we only have the ministry because other countries do.

Others have prescribed a departure from Nigeria's foreign policy foundational principles and philosophy. Onadipe, a Senior Nigeria Foreign Affairs Ministry Officer recommended 'Reciprocal Diplomacy' whereby Nigeria will eschew its big brother posture by attaching strings to assistance it renders any country needing its (Nigeria's) help or support. ${ }^{7}$ This officer does not believe leaning a little on the West and shifting a little towards the East would guarantee the attainment of African countries' MDGs. To him:

Nigeria and indeed the Ministry of Foreign Affairs have conducted our foreign policy successfully based on what we are and what we have i.e. our limitations and inadequacies. We need neither the West nor the East for the attainment of African (Nigerian) MDGs but for corruption and bad governance. However, the East is more forth- coming (Mthembu-Salter, 2009).

The last sentence of this quotation appears like what interests Aliyu Bakori who sees more hope in the aims and objectives of Sino-African Forum. He supports a paradigm shift from what used to be Nigeria's policy on aspect of aid and grant. He believes in constant review of the foreign policy when the need arises. ${ }^{8}$ Though Odein Ajumogobia (then Nigeria's Minister of State for Petroleum) played down the rupture in the relationship between China and Nigeria when Yar' Adua became president. He believes that there is fundamental mutuality and that the notion of 'oil for infrastructure' is still alive. This aligns with Ojo Madueke's (the then Nigerian foreign affairs Minister under Yar' Adua) position which was quoted by journalists and cited in Gregory Mthembu-Salter (2009) that:

We don't feel it diminishes our traditional relationships if we are open to possibilities and relationships with all countries, always keeping in mind our core strategic interests.

What is generally agreed however is that the relationship between Nigeria and China has become a significant feature of World politics. China's pronounced presence in Nigeria is a reality that the country has to face and accommodate. For stakeholders and many international affairs analysts, this could be a moment of opportunity for both sides. The Sino-Nigerian relationship according to Toyin Falola is laden with both an opportunity and a challenge (Okpeh, Wuam and Ayuba, Op. Cit. bp.). 


\section{Evolving a Strategic Partnership with China}

Nigeria obviously has everything to gain by evolving a strategic partnership with China. For instance, Nigeria "would be better off to copy the Chinese character epitomized by discipline, purposeful leadership and deliverability" (Daily Independent, Monday, Nov. 6, 2006). The process of economic development and liberalization embarked upon by China which has turned her into an investment magnet and one of the most competitive markets in the world, should be very instructive to Nigeria. Like in the words of Amadu Sesay (2008), at a public forum, he inferred that, "If the Chinese can close up and make a lot of progress....with humility and proper focus, is it not possible for Nigeria to close up, especially in this era of globalization?". It is thus plausible that an improved investment climate in Nigeria would ultimately guarantee a reliable supply of resources and further unlock vast potentials in the labour market.

African countries as a whole stand to benefit tremendously from an improved relation with China, considering that China is in the contemporary sense the continent's third most important trading partner, behind the U.S. and France and ahead of Britain while Nigeria presents the widest trading platform to China. Such improvements in relations between the two would guarantee the continued flow of business into Nigeria. Moreover, considering that China's investment focus is specifically in the areas of agriculture, light industry, machinery, infrastructure, construction, information technology and tourism, all of which are of primary concern to Africa, it behooves Nigeria to enter into such a strategic partnership in order to secure the country's long term interests. This is against the backdrop that China is especially advanced in technology, oil exploration, seed cultivation and is relatively endowed with cheap and durable light industrial products and machinery all of which are in great demand in Nigeria. In similar way, Nigeria could invariably leverage opportunities that abound with Chinese enterprises, which seem to have sharpened their competitive edge especially in road and railway building, communication systems, irrigation works and energy generation (Daily Independent, Monday, Nov. 6, 2006).

The engagement between Nigeria and China may however be sour as well as sweet. For countries that are not endowed with oil or mineral deposits, higher commodity price impinges on life. Even for producers, risks abound. The World Bank in its recent report argues that Africa's new trade with China opens the way for it to become a processor of commodities and a competitive supplier of cheap goods and services to Chinese consumers. Contra wisely, another report by the organized economic countries for development (OECD), a club of industrialized countries posit that China's appetite for commodities may stifle producers' effort to diversify their economies. The OECD points out that oil rigs and mines creates few jobs and has the propensity to siphon resources from other industries. And if Nigeria is to escape its vulnerability to the capricious movement of world commodity prices, it must start to export more manufactured products. The World Bank aligns with this position by warning that China must end its escalating tariffs on Africa's main-exports.

It behooves China as a developed nation not to act indifferently to repression while Nigeria as a developing State should as a matter of policy remain determined on how it could use her relation with China positively and effectively. Nigeria must prioritize what it is determined to pursue, especially those policies that will "not allow China to dictate domestic politics and exploit" its relation "to the detriment of the" Nigerian "environments and cultures". Nigeria "must ensure that the balance of forces and power needed to guarantee that China would listen to and treat" her "as an equal partner" is maintained (Lumumba-Kasongo, 2007).

An effective way of taking such a policy stance is that Nigeria's current weaknesses must be redressed. Nigeria must restructure its peripheral market and economy and align same with the imperatives of the international political economy, so as to create a departure from its present forced and self-imposed marginalization. It is of great importance that the civil society groups in Nigeria should put in place the networks that would facilitate direct linkages between it and the civil society organizations in China. Nigerian businesses in the same vein ought to present a proactive outlook so that the power of initiating and defining a business relationship is jointly negotiated and made participatory, rather than being left in the hands of their Chinese counterparts alone. Not until these policy issues are addressed, the Nigerian dream of transcending its current relevance status as raw materials supplier and as consumers of finished products (Lumumba-Kasongo, 2007) from strange lands, especially China in the most recent times, will never become a reality. There must be a deliberate action to inject reforms into the nation's political, economic and social institutions, public and private sectors and to reinvigorate good inter-ethnic relationship across the length and breadth of the nation; while clearer rules for national political and financial institutions are being evolved, Nigeria must be resolute by ensuring that its national policy guidelines and priorities are actually its guide. In the words of Onadipe:

Our foreign policy must be tied to getting results. By the way, our domestic policies must be commensurate and consistent with our foreign policy. Our developmental goals must be based on sound domestic policies. Domestically, there must be equity, justice and rule of law, true federalism and fight against corruption for us to achieve those developmental goals. ${ }^{9}$ 
The words by Onadipe, a practicing diplomat is instructive that every citizen of the Nigeria state must wake up to their own responsibilities without which the nation's history of woes would continue to repeat itself while its counterpart states attain sustainable development.

In summary, this study among others crystallizes what Nigeria development challenges are as presented in its Millennium Development Goals (MDGs) and attempted to shed more light on the Nigeria - China relations before and after the Millennium Summit in 2000 and how this relationship has impacted on Nigeria's economic growth, either positively or negatively. It plunges into the evolution of trade, commerce and diplomatic partnership; it considered new perspectives to Nigeria's foreign policy towards China by bringing to fore some of the status quo that must give way to a new paradigm. It took into cognizance the implication of continual obsession of Nigeria with the West in a rapidly changing World Order. It perceived Nigeria's economy as having been structured by the capitalist West to ensure that existing international division of labour allocated to it the role of supplying raw materials and importing finished goods from the industrialized West. Other perspective is that foreign owned extractive industries and agriculture formed monopoly enclaves which serve as a conduit pipe for resources overflow from Nigeria. It was proposed that the economic welfare of Nigeria must no longer be dependent on foreign capital and that time is ripe to redefine Nigeria's foreign policy. It noted that policy of "oil for infrastructure" of Obasanjo is gradually giving way to Yar' Adua's "oil for cash" approach. A rather tall order policy of 'Reciprocal Diplomacy' has been recommended whereby Nigeria will eschew its big brother posture by attaching strings to assistance it renders any country needing its (Nigeria's) help or support.

\section{Conclusion}

Just in line with the earlier position I took, the overall Nigerian foreign policy outlook requires a total overhauling or remodeling in terms of creating new rules or enforcing the old ones, and better still, by embarking on new reforms that touch virtually the entire economy of the nation by reconsidering the philosophical ethos that underpin Nigeria's foreign policy. ${ }^{10}$

\section{Notes}

1). Professors Amadu Sesay and W. A. Fawole of Obafemi Awolowo University, Ile-Ife, Nigeria at the Faculty of Administration's Department of International Relations Seminar series responding to a research proposal on 'China's Economic involvement in Nigeria', 2008.

2). Interview with Sir Elvis Emecheta, head of the Nigerian-Chinese Chamber of Commerce. Lagos, April 2009.

3). Interview with a Senior Nigerian government official, Abuja April, 2009.

4). Interview with Pat Utomi, Lagos, March 2009.

5). Interview with opposition member of the Foreign Affairs Committee of Nigeria's House of Representatives, speaking on condition of anonymity, Abuja, March 2009.

6). A senior official in the ministry of foreign affairs

7). Interview with Patrick Olusola Onadipe, Director, Asia and Pacific Division, Ministry of Foreign Affairs, Abuja, November 2008.

8). Interview with Aliyu Usman Bakori, a Senior official, Asia and Pacific Division, Ministry of Foreign Affairs, Abuja, November 2008.

9). Interview with Patrick Olusola Onadipe, Director, Asia and Pacific Division, Ministry of Foreign Affairs, Abuja, November 2008.

10). see The Punch Online Wednesday, $19^{\text {th }}$ Oct., 2011 by Everest Amaefule; post by Oluwole Gabriel Adekola, Friday, February 25, 2011.

\section{Bibliography}

[1] Adekola, O.G., (2011) M.Sc. Thesis. Nigeria's Foreign Policy towards China in Post Cold War Era (1989-2009).

[2] Ajayi, K. Seeking equality in an unequal world: Nigeria and the permanent Security Council seat aspiration. University of AdoEkiti, Nigeria $22^{\text {nd }}$ Inaugural Lecture delivered on Tuesday, $12^{\text {th }}$ January, 2010. Published by The University of Ado-Ekiti Press (2009).

[3] Akinrinade, O. Foreign policy cooperation in developing states. Obafemi Awolowo University (OAU), Ile-Ife, Nigeria Inaugural Lecture Series 178. OAU Press Limited (2005).

[4] Alden, C. China in Africa (African Argument). Zed books (London/New York, 2007). David Philip (Cape Town, 2007) in association with International African Institute, Royal African Society\& Social Science Research Council.

[5] Alexander, A. "Pawn or Partner". available at http://www.china-in- africa/index.php/option=com content\& task=view\&id=3 \& item $=33$.

[6] Booker, S. and Ann - Louise, C. African Policy Outlook 2006, Africa Action, Washington D.C., U.S. available at http://www.africaaction.org.

[7] Cedoz, F. Thinking beyond OPEC, Journal of International Security Affairs, No. 10, Spring- 2006

[8] Chapter II, section 19 of the 1999 Constitution of the Federal Republic of Nigeria.

[9] China's Foreign Affairs (A compendium by the Department of Policy Planning Ministry of Foreign Affairs People's Republic of China). 2007 edition. World Affairs Press. 
[10] China and Africa. 2006. Excerpts from the speech made by Chinese President Hu Jintao at Nigerian Parliament on April $27,2006$. China Intercontinentals Press.

[11] Clare, M. U.S.: Procuring the World's Oil, Foreign Policy in Focus. available at http://www.atimes.com CODESRIA bulletin. Numbers $1 \& 2,2007$. ISSN 0850-8712.

[12] Fawole, W.A. Understanding Nigeria's Foreign Policy Under Civilian Rule Since 1999: institutions, structures, processes and performance. Ibadan, 2004. College Press Publishers Ltd. ISBN: 978-2194-31-X.

[13] "The Constitution and Nigeria's Foreign Policy". Nigerian Forum, July/August 2000, pp. 218-231.

[14] Gokay, B. "The power shift to the East: the "American Century' is ending". Available at: http://uk.f254.mail.yahoo.com/ym/ShowLetter?box=Inbox\&Msgld=4704_4482176_95561 ...Retrieved 23/05/2006.

[15] Government of the Hong Kong SAR, 2008-03-17. "Chapter I: General Principles".Available at http://www.basiclaw.gov.hk/en/basiclawtext/chapter_1.html. (Retrieved 2009-11-01).

[16] Hale, D. "China's Economic Take Off; Implication for Africa”. Brenthurst Discussion Papers 1/2006 http:/www/the Brenthurst foundation.org.

[17] Kynge, J. China Shakes the World: A Titan's Rise and Troubled Future-and the Challenge for America. First Mariner Books (New York, 2007).

[18] Luo, Jing. Over A Cup of Tea: An Introduction to Chinese Life and Culture. (China: University Press of merica, 2004). ISBN 0761829377

[19] Medeiros, E.S. China-Africa: the African dimension in China's foreign policy. Rand Corporation [126] 02 Oct. 2006. available at http://www.china-nigeria

[20] Mimiko, N.O. Swimming against the tide: development challenge for the long- disadvantaged in a fundamentally schewed global system. Inaugural lecture delivered at Oduduwa Hall, Obafemi Awolowo University, Ile-Ife, Nigeria on Tuesday, $12^{\text {th }}$ October , 2010. Obafemi Awolowo University Press Ltd., series 233.

[21] Next , 17 April, 2010: editorial. available at http://234next.com/csp/csm/sites/Next/Home/5556059146/nigerias_foreign_policy_.csp

[22] Nico-Colombant, China's New African Oil Ties Create Concerns, September 29, 2004 available at www.voanews.com

[23] Ogunsanwo, A. A paper titled: "Nigeria-China" written by him in response to the renewed relationship between Nigeria and China in the twenty-first century. He is a professor of International Relations currently at the Leads City University, Ibadan Nigeria.

[24] Okpokpo, E. 1999. The Challenges facing Nigeria's Foreign Policy in the Next Millenium 3(2): 4. [online] URL: http://web.africa.ufl.edu/asq/v3/v3i3a16.htm

[25] Olebune, C. nel-mag.org. His article titled "Nigeria-China Economic Romance: The Good, The Bad, or The Ugly", January 2007. Available at: http://www.africanevents.com/Essay-olebune-ChinaEcoRomance.htm. Retrieved 15/06/2009.

[26] Omole, B. Nigeria, France and the Francophone States: the joy and anguish of a regional power. Inaugural lecture delivered at Oduduwa Hall, Obafemi Awolowo University, Ile-Ife, Nigeria on Tuesday, $25^{\text {th }}$ May, 2010. Obafemi Awolowo University Press Ltd., series 226.

[27] Osondu, A. Critical assessment of China's economic involvement with Nigeria. M.Sc. Thesis, Obafemi Awolowo University, IleIfe, Nigeria (2008).

[28] Report of the Commission for Africa 2005: Africa Oil, our Common Interest. available at http://www.afroilc.com

[29] Rodney, W. How Europe Underdeveloped Africa. (London: Bogle-L 'Ouverture Publications/ Dar-es-Salaam: Tanzania Publishing House, 1972).

[30] Southall, R. and Melber, H. (ed). A New Scramble for Africa? Imperialism, Investment and Development. University of KwaZuluNatal Press (South Africa, 2009).

[31] Synge R, 'Nigeria: Recent history', in Frame 1 (ed.), Africa South of the Sahara 2008. (London: Europa, 2007).

[32] The Punch, Monday 11 Oct., 2010. “Whose Interest does Nigeria's Foreign Policy serve?"Articleby Amaefule, E. available at http://www.punching.com/Articl.aspx?theartic=Art201010111=74148. (Retrieved 28/02/2011).

[33] Turshen, M. The Politics of Oil in Africa, 2004. available at http://www.s\&fonline.com

[34] Upton, C., Kretzschmar, W. A., Konopka, R. Oxford Dictionary of Pronunciation for Current English. Oxford University Press (2001)

[35] Utomi P, China and Nigeria. Washington, DC: Center for Strategic and International Studies, 2008, p. 40

[36] Wikipedia, the free encyclopedia: China.org.cn. " One Country, Two Systems. Retrieved on 2008-01-04.

[37] Wong, L. The Impact of Asian National Oil Companies in Nigeria. (London: Chatham House, 2009).

[38] Zimako, O. Z. Face of a Nation: Democracy in Nigeria, Foreign Relations andNational Image. Modern Approach (India, 2009).

\begin{abstract}
About the author
- Oluwole G. Adekola currently teach international politics in Obafemi Awolowo University, Ile-Ife, Nigeria. He holds a B. Sc and an M. Sc. degree in Political Science from the University of Ibadan, Nigeria in 1988 and 2002, respectively; he holds a second M.Sc. degree in International Relations from Obafemi Awolowo University, Ile-Ife, Nigeria (2011). He is currently pursuing a PhD in Politics and International Relations (with emphasis to Humanitarian Crisis and Peacebuilding) at Swansea University, Swansea, Wales, United Kingdom. His research interest is in Peace/Conflict/Developmental Issues and Afro-Asia Studies.
\end{abstract}

